\title{
Government failure and success: A trans-Tasman comparison of two insulation subsidy schemes
}

\author{
Nicholas Preval, Jenny Ombler, Arthur Grimes, \\ Michael Keall and Philippa Howden-Chapman ${ }^{1}$
}

In the wake of the 2008 Global Financial Crisis (GFC), the governments of Australia and New Zealand undertook a variety of economic stimulus measures, including home insulation and heating retrofit programs. Australia's Home Insulation Program (HIP) ended early and in disarray (Hawke, 2010; Kortt and Dollery, 2012) while New Zealand's Warm Up New Zealand: Heat Smart (WUNZ:HS) program was considered a success, outperforming agreed targets and time frames and producing a variety of health and other benefits (Grimes et al., 2011, 2016; O'Sullivan, Barnard, Viggers and Howden-Chapman, 2016; Preval, Keall, TelfarBarnard, Grimes and Howard-Chapman, 2017).

Effectively, across these two related schemes, one resulted in government failure (Le Grand, 1991) while the other proceeded as well as (or better than) expected. We examine key proximate and more fundamental reasons behind this differential experience. The paper identifies differences in the key characteristics of the two programs and the political and policy contexts that could explain such differing outcomes. These include differences in governance, program targets, program design, implementation, evaluation and the influence of prior public health research.

While economic stimulus was an aim in each case, our analysis shows that such stimulus needs to be informed by prior research and/or prior implementation experience, especially if the program is to be implemented quickly. The lack of each of these factors in the Australian HIP case meant that its (rushed) decisions were poorly informed, resulting in failure of both the insulation and stimulus aims of

1 npreval@allenandclarke.co.nz, University of Otago and Allen and Clarke Policy and Regulatory Specialists; University of Otago; Victoria University of Wellington and Motu Research; University of Otago; University of Otago. 
the scheme. By contrast, the New Zealand WUNZ:HS scheme was underpinned by significant prior research and implementation experience, meaning that the stimulus decision rested on an appropriate information base.

The paper first provides background to the two schemes, including the program structures and details about product choices and installation methods. These sections set out the proximate causes of failure versus success of the two schemes. We then analyse the underlying causes of the differing results across countries by analysing the processes of policy advice and consultation, and of implementation and evaluation of the schemes. Some concluding comments highlight our key findings.

\section{Background}

When the 2008 GFC resulted in the collapse of non-bank financial institutions and dampened demand in sectors such as construction, both Australia and New Zealand's central governments responded with a variety of Keynesian economic initiatives intended to stimulate growth and reduce unemployment. Both developed or accelerated home energy efficiency retrofit programs. In addition to providing stimulus, these programs were intended to address the high proportion of homes that did not meet minimum insulation standards: an estimated 700,000-900,000 homes in New Zealand were under-insulated (Johnson, Howden-Chapman and Eaqub, 2018), and 2.2 million homes lacked insulation entirely in Australia (Hanger, 2014). ${ }^{2}$

New Zealand's WUNZ:HS was a four-year (2009-2013), NZ\$347-million program administered by the Energy Efficiency and Conservation Authority (EECA) that was designed to partially fund a range of home insulation and heating retrofits; primarily ceiling and floor insulation and improved heating. The National government program was a development of an earlier, ongoing scheme called 'Energywise Homes' that had been instigated by the previous Labour Government and had been operational since 2003. As a response to the GFC, the stimulus potential of the program led to its expansion into WUNZ:HS with greater investment from the government. Ministerial and Cabinet papers leading to the decision reiterated energy and health co-benefits that underpinned the Energywise program, and emphasised the ways in which greater investment would also provide a stimulus effect (Hull, 2009; McNicholas, 2009). Based on prior research, WUNZ:HS was predicted to reduce energy expenditure and also to produce public health co-benefits resulting from increases in indoor temperatures and reductions in mould and allergens in houses receiving insulation and/or heating, which had been established by randomised community trials in New Zealand (Chapman, Howden-Chapman, Viggers, O'Dea

2 These figures are estimates, as neither country conducts regular random, nation-level housing quality surveys. 
and Kennedy, 2009; Howden-Chapman et al., 2007, 2008). Subsequent evaluations confirmed that the program produced both energy savings (Grimes et al., 2016) and health benefits (Preval, 2012, 2015; Preval et al., 2017; Telfar Barnard et al., 2011). The program was subsequently continued as Warm Up New Zealand: Healthy Homes with reduced funding (EECA, 2013) and has more recently been continued under the incoming Labour Government.

Australia's HIP was a two-and-a-half-year, AU\$2.7-billion federal program administered by the then Department of the Environment, Water, Heritage and the Arts (DEWHA). The scheme part-funded home ceiling insulation retrofits. While the scheme was predicted to have some energy efficiency co-benefits, it was primarily focused on economic stimulus (Auditor General, 2010). The program was derived from a set of earlier proposals to improve energy efficiency, as part of a wider Carbon Pollution Reduction Scheme. Where these proposals discussed insulation, they emphasised job creation, with energy saving co-benefits. They had not been developed into policy prior to the development of the HIP (Hanger, 2014, p. 6). The HIP was trialled in early 2009 (Phase One) before being rolled out in July 2009 (Phase Two). During its brief period of operation, four workers lost their lives while undertaking the work and the program was beset with claims of fraud and poorquality work which ultimately required costly remediation. The HIP was formally ended in February 2010 after months of controversy. Extensive investigation of the HIP, which included four government-commissioned reports (Auditor General, 2010, Hanger, 2014; Hawke, 2010; Senate Committee, 2010) and three peerreviewed articles (Dollery and Hovey, 2010; Kortt and Dollery, 2012; Lewis, 2010), identified numerous design and implementation failures.

Table 1 summarises the key characteristics and timelines of the two programs.

Table 1. Key program characteristics

\begin{tabular}{|l|l|l|}
\hline & HIP & WUNZ:HS \\
\hline $\begin{array}{l}\text { Start date - intended } \\
\text { completion date }\end{array}$ & 3 Feb 2009 - 31 Dec 2011 & 1 July 2009 - 30 June 2013 \\
\hline Actual dates & $\begin{array}{l}\text { Phase One (3 Feb 2009 - } \\
\text { 30 Jun 2009) } \\
\text { Phase Two (1 Jul 2009 - } \\
\text { 19 Feb 2010) } \\
\text { Phase Three (19 Feb 2010 - } \\
\text { remediation only) }\end{array}$ & 1 July 2009 - 30 June 2014 \\
\hline Program funding & $\begin{array}{l}\text { AU\$ 2.7 billion (reduced to } \\
\text { AU\$2.45 billion, 2 Nov 2009) }\end{array}$ & NZ\$347 million \\
\hline $\begin{array}{l}\text { Primary program } \\
\text { implementation }\end{array}$ & DEWHA & EECA \\
\hline
\end{tabular}




\begin{tabular}{|c|c|c|}
\hline & HIP & WUNZ:HS \\
\hline $\begin{array}{l}\text { Intended outcome } \\
\text { (actual outcome) }\end{array}$ & \begin{tabular}{|l} 
Improved ceiling insulation for \\
2.2 million homes (approximately \\
1.16 million completed) \\
\end{tabular} & $\begin{array}{l}\text { Retrofitted insulation and space } \\
\text { heating for } 188,000 \text { homes } \\
\text { (approximately } 234,000 \text { completed) }\end{array}$ \\
\hline Predicted co-benefits & $\begin{array}{l}\text { Economic stimulus } \\
\text { Reductions in energy use and } \\
\text { energy efficiency improvements } \\
\text { Reduced CO2 emissions } \\
\text { Improved comfort }\end{array}$ & $\begin{array}{l}\text { Health savings } \\
\text { Economic stimulus } \\
\text { Reductions in energy use and } \\
\text { energy efficiency improvements } \\
\text { Reduced CO2 emissions } \\
\text { Improved comfort }\end{array}$ \\
\hline $\begin{array}{l}\text { Retrofits available } \\
\text { under scheme }\end{array}$ & Ceiling insulation & $\begin{array}{l}\text { Ceiling and floor insulation } \\
\text { (mandatory to have both if possible), } \\
\text { vapour barriers, draught excluders, } \\
\text { hot water pipe lagging, cylinder } \\
\text { wraps; } \\
\text { Clean heating (either a heat pump, } \\
\text { wood burner, pellet burner or } \\
\text { a reticulated gas heater) }\end{array}$ \\
\hline $\begin{array}{l}\text { Funding available } \\
\text { to participants/ } \\
\text { consumers }\end{array}$ & $\begin{array}{l}\text { AU } \$ 1,600 \text { per home for ceiling } \\
\text { insulation (reduced to AU } \$ 1,200 \text {, } \\
2 \text { Nov 2009), paid by central } \\
\text { government }\end{array}$ & $\begin{array}{l}33 \% \text { central government funding for } \\
\text { ceiling and floor insulation, draught } \\
\text { proofing, moisture barriers and } \\
\text { remediation (maximum NZ } \$ 1,300) \text {, } \\
\left(60 \%{ }^{*} \text { funding for low-income }\right. \\
\text { households or landlords of low- } \\
\text { income households - no maximum) } \\
\mathrm{NZ} \$ 500 \text { central government funding } \\
\text { towards clean heater }\left(\$ 1200^{*} \text { if }\right. \\
\text { low-income household); funding for } \\
\text { clean-heaters eventually phased out } \\
\text { of program } \\
\text { * Additional funding/more complex } \\
\text { funding arrangements available from } \\
\text { charities, local government or lines } \\
\text { companies }\end{array}$ \\
\hline $\begin{array}{l}\text { Service delivery } \\
\text { model }\end{array}$ & $\begin{array}{l}\text { Participants/consumers contracted } \\
\text { directly with installer. } \\
\text { Phase } 1 \text { (3 Feb } 2009 \text { - } \\
30 \text { Jun 2009): } \\
\text { Claim required two quotes and a } \\
\text { site inspection (Senate Committee, } \\
\text { 2010). Money was paid upfront by } \\
\text { participants/consumers who then } \\
\text { claimed a rebate processed and } \\
\text { paid by DEWHA. } \\
\text { Phase } 2 \text { (1 Jul } 2010 \text { - } 19 \text { Feb 2010): } \\
\text { Installers were paid rebate amount } \\
\text { directly following claim via Medicare } \\
\text { Australia. Consumers often did not } \\
\text { pay any money at all. }\end{array}$ & $\begin{array}{l}\text { Contract between consumers and } \\
\text { service providers. } \\
\text { Consumers paid service providers } \\
\text { directly (less rebate), service } \\
\text { providers obtained rebate from } \\
\text { EECA via claim. Consumers were } \\
\text { able to pay via mortgage extension, } \\
\text { interest-free loan, or rates. } \\
\text { Consumers in some cases had } \\
\text { access to additional funding } \\
\text { from third parties such as } \\
\text { local government and charity } \\
\text { organisations. }\end{array}$ \\
\hline
\end{tabular}

Note: $\mathrm{CO}_{2}=$ carbon dioxide.

Source: Preval (2015). 


\section{Program structure}

Many of the proximate failures of the Australian HIP can be linked directly to program design choices such as minimal program entry requirements for installers, and a rebate structure which did not require home owner contributions. It was relatively easy for installer organisations to register under the HIP as they were only required to have a valid Australian Business Number and to agree to the Terms and Conditions of Registration; 7,841 completed at least one installation (Senate Committee, 2010). The quick uptake limited the ability of Medicare to confirm that registered installers met program entry requirements in a timely manner, and meant that a number of dishonest operators were able to enter the HIP and operate unchecked, either billing for work not completed, or otherwise deliberately circumventing program regulations. Hawke (2010, p. viii) cites, 'disturbing claims about the high level of fraud perpetrated by unscrupulous operators. Despite some safeguards against fraud, no one foresaw the possible extent of potential malfeasance which was simply alarming'.

An equal concern was the retrofitting of insulation by unqualified and/or inexperienced installers, which was linked to poor-quality workmanship, dangerously installed insulation and to the deaths of four installers, which ultimately led to the end of the HIP. Installers needed only generic health and safety training and to be supervised by somebody with: 'prior industry experience; a trade qualification in an approved trade; or insulation specific training' (Auditor General, 2010, p. 104). The decision to require only supervisors to meet minimum competency standards was made by DEWHA in consultation with a range of stakeholders, and the trade-off between requiring minimum standards for all workers and just supervisors was explicitly considered; however, it was decided that 'it would not be possible to implement, given the short period of time available and the need for low barriers to entry to the program' (Auditor General, 2010, p. 107). It was later reported that supervision was often minimal, meaning that unqualified and inexperienced installers were placed in very difficult situations (Lewis, 2010).

By contrast, there were only about 60 service providers under the WUNZ:HS program (EECA official, personal communication, 2010). The average WUNZ:HS service provider retrofitted approximately 780 homes per year over the course of the program, which contrasts with approximately 150 per year for installers under the HIP. WUNZ:HS service providers were required to complete an annual review as a condition for contract extension, and acceptance of stringent auditing requirements (EECA, 2009). Small operators, such as those who thrived under the HIP, were unlikely to have gained entry to the WUNZ:HS program, given the extensive tendering process, while any service provider that did gain entry to the program would have more to lose if found to be engaging in fraudulent practices. WUNZ:HS did not explicitly set minimum installer competencies, but the 
request for proposals stated that when considering proposals 35 per cent weight would be given to 'capability', which included 'proven personnel and experience or capability in installing EECA approved products' and 'evidence of ability to complete work to the Standards outlined in EECA's Audit and Quality Manual' (EECA, 2009, p. 12). Even with these barriers to entry, audits during the early months of WUNZ:HS's operation found a problematic failure rate for a mixture of administrative and safety reasons. It was, however, possible for EECA to swiftly address these issues with higher rates of auditing and appropriate communication with the 60 service providers.

The other fundamental difference in the design of the two programs was the fact that Phase Two of the HIP did not require a household contribution unless the total cost of an insulation retrofit exceeded a preset limit, with rebates paid directly by the government. Because the majority of HIP retrofits were below the threshold for household contribution, most households had limited motivation to make informed decisions about which installation company to choose, and to monitor the quality of work (which is difficult even when householders are motivated due to information asymmetries in this industry) (Senate Committee, 2010). As with many of the other problematic aspects of the Australian HIP program design, there was awareness of these issues among senior officials during the design phase, including explicit mention of these issues in the Minter Ellison risk register published in April 2009 (Senate Committee, 2010). By contrast, the WUNZ:HS rebate structure, which required home owners or third parties to contribute financially, can be assumed to have encouraged a higher degree of consumer vigilance.

\section{Product inclusion and installation methods}

Although the two programs had different scopes, the common element of both was insulation. The treatment of foil insulation is particularly interesting as a basis of comparison. Foil insulation is an insulation material that reflects a high proportion of radiant heat. Foil insulation was available under the HIP. Tragically, electrocution killed three installers who inadvertently pierced live wiring with metal staples during foil insulation installation (Senate Committee, 2010), and poorly installed foil retrofits meant that many ceilings were potential fire or electrocution hazards, later requiring checking, modification or removal of the insulation retrofitted (Auditor General, 2010). Industry consultation prior to the start of the program had raised awareness of the risks of foil insulation but, as was also the case with proposed minimum installer qualifications, some members of the established insulation industry opposed changes to current practice that included the use of metal staples, citing the lack of previous issues with these products (Hawke, 2010). The Senate Committee report concluded that it was the combination of inexperienced installers and products requiring skilled installation that led to the foil-related safety issues. 
Foil insulation was not available under the WUNZ:HS, although foil floor insulation had been available under a previous EECA program until mid-2008. ${ }^{3}$ In 2007, several New Zealand installers died of electrocution while installing foil insulation (not under EECA administrated programs), and both safety and other issues such as a lack of durability led to the eventual exclusion of foil from EECAfunded programs including WUNZ:HS. During a stakeholder meeting early in Phase One of the HIP, the New Zealand deaths were discussed, but this and other evidence did not dissuade Australian officials from including foil in their program (Senate Committee, 2010).

\section{Policy advice and consultation}

The processes by which each of the HIP and WUNZ:HS policies were designed reflects different prior experience with insulation schemes, different policy environments and different research profiles. The HIP was designed prior to regulatory reforms in Australia, meaning that government programs did not then require a regulation impact statement or cost-benefit analysis (R. Reilly, Director of Office of Best Practice Regulation, personal communication, 12 March 2019). Since reforms in 2013, government programs are normally required to go through these processes, which may have identified some risks or limitations of the proposed program. Instead, policy decisions were made through the Strategic Priorities and Budget Committee (SPBC), a subcommittee of four members of Cabinet. The full Cabinet was briefed on the overall policy on the same day that the HIP was announced (Hanger, 2014, pp. 78-81). The SPBC was criticised as sidelining Cabinet while concentrating decision-making too heavily within the SPBC (Kefford, 2013).

The 2014 Royal Commission of Enquiry report on the HIP notes that there was a significant lack of relevant expertise among all who were charged with the design and implementation of the policy. Risk was identified early in the HIP policy design process. Subsequently, Minter Ellison Consultants were appointed as 'external risk consultants'. The report suggests that accounting for risk failed in two primary ways. First, DEWHA had earlier decided that responsibility for compliance with health and safety legislation lay with the employer, not with the government. Second, the process undertaken by Minter Ellison Consultants with DEWHA was 'deficient' (Hanger, 2014, p. 119), and did not ensure that particular expertise on the risks surrounding this type of program was included. As a result of both of these failures, injury to installer was not included on the final risk register and was only reinstated after a death had occurred. Summarising issues around risk more generally, the report notes that frank advice about risk to senior officials and 
Ministers should include practical implications and risks for those directly involved in programs, policies or projects rather than a primary focus on reputational and political risks (Hanger, 2014, p. 310).

In assessing some of the decisions that undermined the HIP, the Senate Committee suggested that the Australian government 'should establish a dedicated and industryindependent program to research insulation systems and help develop efficient and effective insulation policy' (Senate Committee, 2010). However, while it is tempting to agree with the Senate Committee (2010) that Australia would have benefited from an independent scientific facility in Australia able to research the properties of the various systems and advise on insulation policy in context of overall energy efficient housing goals', the unwillingness of the federal government and senior officials to consider modifications that might have compromised the economic stimulus effect of the HIP led them to give little weight to the results of the consultation and risk assessment processes. This resulted in few changes in practice that might have mitigated risk, or have had a greater impact on co-benefits, largely due to the perceived delay this would have caused to the implementation of the program which was a primary concern (Hanger, 2014, pp. 25-26). The 2014 Royal Commission of Enquiry into the HIP noted: 'careful planning was sacrificed to the perceived need for speed' (Hanger, 2014, p. 28). Furthermore, the Enquiry highlighted the need for measures that empower public servants to disagree with politicians, a difficult task when the security of tenure of public officials has been eroded in Australia, leading to fear that insecure positions might be compromised if advice given is unpalatable to Ministers (Hanger, 2014). The Enquiry recommended cultural changes that would encourage public servants, and also educate Ministers on their role in receiving advice (Hanger, 2014, p. 307). Understanding why the stimulus goal overrode other considerations, which arguably contributed to program failure, leads us to look at the wider policy context of the two countries.

Insulation has widely been accepted as a means of improving population health in New Zealand and insulation programs have a long history. Two organisations fill the policy advice role identified by the Senate Committee in the New Zealand context. First, New Zealand has the Health Research Council-funded He Kainga Oranga/ Housing and Health Research Programme, a publicly funded university-based research organisation, which has provided considerable independent, policy-relevant research on the value of insulation and heating retrofits. Second, New Zealand has the Building Research Association of New Zealand Ltd (BRANZ), an independent organisation funded by a levy on consented building projects which must be used to 'promote and conduct building-related science and research ... [including] testing and assurance for insulation products, and technical knowledge about how to correctly specify and install insulation and the consequences of poor installation' (BRANZ, 2010, p. 15). 
In particular, He Kainga Oranga's research has had a great deal of influence in raising the perception of links between health and housing in New Zealand over the period 1996-2010 (Bierre and Howden-Chapman, 2017; Carroll, Blewden and Witten, 2008; Fougere, Howden-Chapman and Bennett, 2012). This rise coincides with publication of key results from randomised controlled trials demonstrating the health and energy co-benefits of retrofitted insulation (Chapman et al., 2009; Howden-Chapman et al., 2007). It is now widely recognised in New Zealand that there is a research-proven link between poor housing quality and health (Carroll, Blewden and Witten, 2008).

At the time that WUNZ:HS was being developed, the consensus view linking insulation and health was well established. Furthermore, prior to WUNZ:HS, there was considerable experience with implementing publicly subsidised insulation schemes with EECA having already implemented numerous insulation and energy efficiency retrofit schemes. Cross-party support for insulation retrofit programs was evidenced by the previous government's planned NZ\$1-billion insulation retrofit program, which was ultimately superseded by WUNZ:HS. New Zealand had also previously faced a leaky building crisis (Building Industry Authority, 2002), demonstrating the long-term consequences of poorly informed short-term decisions with long-term impacts on housing quality and health (Douwes and HowdenChapman, 2011; Howden-Chapman, Ruthe and Crichton, 2011).

By contrast, we found little research about home insulation and its benefits in the Australian context. Savings were identified as co-benefits resulting from the HIP but there was little discussion of any health co-benefits (Chapman, Preval and Howden-Chapman, 2017; Howden-Chapman and Chapman, 2012). While Australia is a drier and warmer country than New Zealand on average, analysis by Cheng et al. (2010) indicates that its citizens can experience hazardously high and low indoor temperatures (Basu, 2009; Pierse et al., 2013), both of which can be ameliorated by insulation. Given the value placed on the co-benefits of insulation, which have been internationally accepted (International Energy Agency, 2015; World Health Organization, 2011), and the large body of institutional knowledge and previous uptake within New Zealand, greater weight appears to have been placed on quality rather than quantity of delivery in New Zealand relative to Australia.

\section{Implementation}

The HIP and WUNZ:HS were funded and implemented by federal and national governments respectively. Reviews of the two programs suggest that federal government administration was not ideal in the case of the HIP, as operational policies were typically carried out at state level. Kortt and Dollery (2012) note that the HIP was predicted to have both state and national benefits. Consistent with the 
literature on subsidiarity (Wills, 2016), they postulate that central government has an advantage in terms of revenue-gathering while state government has a comparative advantage in the administering of programs that require local knowledge and local experience. This suggests that the HIP would have functioned better as a centrally funded, but state-implemented program, particularly given that many states had previous experience administering similar programs (Hawke, 2010; Kortt and Dollery, 2012). This argument is consistent with the many complaints and concerns that state governments voiced during both the design and implementation stages of the HIP (Lewis, 2010; Senate Committee, 2010).

By contrast, New Zealand has a unitary (as opposed to federal) system of government and at 20 per cent of Australia's population, is closer in population size to that of a single Australian state. EECA, the implementing agency for WUNZ:HS, had considerable previous national experience administering similar programs and thus, using the criteria presented in Kortt and Dollery (2012), New Zealand's centralised approach to both revenue-gathering and program administration is likely to have been preferable.

Although the degree of centralisation may have influenced the relative success of the two programs, many of the difficulties faced during the implementation of Australia's HIP resulted from choices made during the design phase of the program. A key example is the massive increases in monthly retrofits during the period July 2009 - November 2009, which resulted from decisions designed to maximise the stimulus effect of the program. Given the high levels of demand, reports of poor workmanship and fraud could not be addressed in a timely manner as backlogs of complaints made the HIP's monitoring and auditing program relatively ineffective (Auditor General, 2010).

In New Zealand, EECA also experienced difficulties in the early stages of WUNZ:HS, including capacity issues, but these difficulties did not overwhelm its systems. For example, EECA was able to improve poor-quality workmanship by raising external audit rates from 5 per cent to 10 per cent and in some cases demanding that offenders check all previous work. Such an approach would have been much harder to implement with many small providers and a greater rate of uptake.

While the two programs did have different rates of uptake, differences in program implementation were also influenced by differences in organisational experience. EECA's long history of administering similar programs to WUNZ:HS gave it an advantage relative to DEWHA, which, as a policy development-based agency, had not implemented a program of this kind. The Senate Committee report noted that DEWHA did not have staff with experience in the insulation industry and that the management structure was not suitable for a program of the size of the HIP. 
In Australia, in addition to capacity and experience issues, there was a clear reluctance by politicians and senior officials to take effective action to address problems during the implementation phase if this might compromise the speed of the rollout, again reflecting the overriding stimulus goal (Lewis, 2010). The Royal Commission Report notes that certain considerations were put aside, or inadequately attended to, in the interest of expediency. Two examples of this are the failure to exclude foil insulation, and a truncated training program, both of which were cited as decisions made in favour of the stimulus objective at the expense of health and safety. Furthermore, the report noted that the program's expediency objective compromised 'usual protections' such as an audit and compliance regime (Hanger, 2014).

An argument could be made that stimulus in the face of economic slowdown is worthwhile in itself and in that respect the HIP scheme may be viewed as a success. However, stimulus can be achieved in multiple ways. A scheme characterised by poor workmanship led to both poor outcomes for home owners and discredited future insulation schemes, resulting in harms that would not have occurred with other forms of stimulus. The opportunity cost of using resources for the HIP rather than some other stimulus program is a real resource cost for the Australian economy.

\section{Policy evaluation}

A formal evaluation process was not built into Phase Two of the Australian HIP prior to the start of the program, although Phase One of the program did serve as a design and process evaluation tool, as did the various consultation processes. Ultimately, the swiftly commissioned independent Hawke Review served as a design and process evaluation for Phase Two, helping to finalise the suspension of the program; however, as noted in the Senate Committee report, '[t]he government's move to commission an independent review of the HIP (the Hawke Review) was too little, too late and should have been undertaken earlier so that the findings could be used to improve the HIP' (Senate Committee, 2010, pp. xiv). By contrast, the WUNZ:HS program included funding for an extensive outcome evaluation, which was timed so that results could lead to program modification or even end the program (Grimes et al., 2011). In the Australian case, it seems likely that the absence of a formal outcome evaluation process reflected the haste with which the HIP and other stimulus programs were rolled out. 


\section{Conclusion}

There is a great deal that can be learned from this comparative case study of causes of government success and failure. The comparison of policy contexts illustrates the valuable contribution that prior experience with similar programs and prior national and international research can make in influencing key policy decisions. It is possible that research undertaken outside of the country carried insufficient weight to influence Australian policymaking. However, the failure of the HIP demonstrates the limits of research, especially given the dearth of prior policy-related experience, in the face of the hasty pursuit of a politically driven goal. The focus on expedience undermined the quality of the program. Ultimately, the cancellation of the scheme truncated ongoing stimulus effects.

A government focus on quantity rather than quality of provision, coupled with a poor information base and poor governance arrangements (especially federal government involvement in what is more properly a state government initiative), can - and did - result in a failed program. The comparison with the contemporaneous successful program in New Zealand shows that such government failure is not inevitable for this type of scheme. A key lesson is that a research-informed scheme that is informed by prior experience and that builds in appropriate evaluation steps is likely to outperform a simple stimulus-driven package. The result is a successful and sustainable stimulus package that achieves long-term health benefits for citizens.

\section{References}

Auditor General. (2010). Home insulation program (Audit Report No. 12 2010-11). Canberra: Australian National Audit Office.

Basu, R. (2009). High ambient temperature and mortality: A review of epidemiologic studies from 2001 to 2008. Environmental Health, 8(1), 40.

Bierre, S. and Howden-Chapman, P. (2017). Telling stories: The role of narratives in rental housing policy change in New Zealand. Housing Studies, 1-21.

Building Industry Authority. (2002). Report of the overview group on the weathertightness of buildings to the Building Industry Authority. Wellington: Building Industry Authority.

Building Research Association of New Zealand (BRANZ). (2010). Annual review 2010. Wellington: BRANZ Inc.

Carroll, P., Blewden, M. and Witten, K. (2008). The social sciences and policy-research use in Building research capability in the social sciences (BRCSS). Auckland: Centre for Social and Health Outcomes Research and Evaluation, Massey University. 
Chapman, R., Howden-Chapman, P., Viggers, H., O’Dea, D. and Kennedy, M. (2009). Retrofitting houses with insulation: A cost-benefit analysis of a randomised community trial. Journal of Epidemiology and Community Health, 63(4), 271-277.

Chapman, R., Preval, N. and Howden-Chapman, P. (2017). How economic analysis can contribute to understanding the links between housing and health. International Journal of Environmental Research and Public Health, 14(9), 996.

Cheng, M., Galbally, I., Gillett, R., Keywood, M., Lawson, S., Molloy, S. and Powell, J. (2010). Indoor air in typical Australian dwellings: A report to the Air Quality Section, Environment Standards Branch, Department of the Environment, Water, Heritage and the Arts. Australia: Australian Government Department of the Environment, Water, Heritage and the Arts.

Dollery, B. and Hovey, M. (2010). Australian federal government failure: The rise and fall of the Home Insulation Program. Economic Papers: A journal of applied economics and policy, 29(3), 342-352.

Douwes, J. and Howden-Chapman, P. (2011). An overview of possible health effects from exposure to 'leaky buildings'. In The Leaky building crisis: Understanding the issues (pp. 71-84). Wellington: Thomson Reuters.

Energy Efficiency and Conservation Authority (EECA). (2009). Request for proposal for service providers to seek funding under the ENERGYWISE ${ }^{\mathrm{TM}}$ Warm Up New Zealand: Heat Smart Programme. Wellington: Energy Efficiency and Conservation Authority.

Energy Efficiency and Conservation Authority (EECA). (2013). Warm Up New Zealand: Healthy Homes. Retrieved from: www.energywise.govt.nz/funding-and-programmes/ insulation-programme.

Fougere, G., Howden-Chapman, P. and Bennett, J. (2012). Review of New Zealand media references to housing and health. Unpublished raw data.

Grimes, A., Preval, N., Young, C., Arnold, R., Denne, T., Howden-Chapman, P. and TelfarBarnard, L. (2016). Does retrofitted insulation reduce household energy use? Theory and practice. The Energy Journal, 37(4). doi.org/10.5547/01956574.37.4.agri.

Grimes, A., Young, C., Arnold, R., Denne, T., Howden-Chapman, P., Preval, N. and TelfarBarnard, L. (2011). Warming up New Zealand: Impacts of the New Zealand Insulation Fund on metered household energy use (Paper prepared for Ministry of Economic Development). Wellington: Motu Economic and Public Policy Research.

Hanger, I. (2014). Report of the Royal Commission into the Home Insulation Program. Canberra: Attorney-General's Department.

Hawke, A. (2010). Review of the administration of the Home Insulation Program. Canberra: Australian Department of Climate Change and Energy Efficiency.

Howden-Chapman, P. and Chapman, R. (2012). Health co-benefits from housing-related policies. Current Opinion in Environmental Sustainability, 4, 414-419. 
Howden-Chapman, P., Matheson, A., Crane, J., Viggers, H., Cunningham, M., Blakely, T., Cunningham, C., Woodward, A., Saville-Smith, K. and O'Dea, D. (2007). Effect of insulating existing houses on health inequality: Cluster randomised study in the community. BMJ, 334(7591), 460-469.

Howden-Chapman, P., Pierse, N., Nicholls, S., Gillespie-Bennett, J., Viggers, H., Cunningham, M., et al. (2008). Effects of improved home heating on asthma in community dwelling children: randomised community study. BMJ, 337, 852-855.

Howden-Chapman, P., Ruthe, C. and Crichton, S. (2011). Habitable houses: Lessons learned? In The leaky building crisis: Understanding the issues (pp. 303-315). Wellington: Thomson Reuters.

Hull, L. (2009). Design of a large scale insulation fund. Unpublished report by Ministry of Economic Development.

International Energy Agency. (2015). Capturing the multiple benefits of energy efficiency. Paris: International Energy Agency.

Johnson, A., Howden-Chapman, P. and Eaqub, S. (2018). A stocktake of New Zealand's housing. Wellington: New Zealand Government.

Kefford, G. (2013). The presidentialisation of Australian politics? Kevin Rudd's leadership of the Australian Labor Party. Australian Journal of Political Science, 48(2), 135-146. doi.org/10.1080/10361146.2013.786676.

Kortt, M.A. and Dollery, B. (2012). The Home Insulation Program: An example of Australian government failure. Australian Journal of Public Administration, 71(1), 65-75.

Le Grand, J. (1991). The theory of government failure. British Journal of Political Science, 21(4), 423-442.

Lewis, C. (2010). The Home Insulation Program policy debacle: Haste makes waste. Public Policy, 5(2), 83.

McNicholas, J. (2009). Increasing central government investment in residential energy efficiency programmes. Unpublished report by Ministry of Economic Development.

O'Sullivan, K., Telfar Barnard, L., Viggers, H. and Howden-Chapman, P. (2016). Child and youth fuel poverty: Assessing the known and unknown. People, Place \& Policy Online, 10(1). Retrieved from: extra.shu.ac.uk/ppp-online/child-and-youth-fuel-povertyassessing-the-known-and-unknown/.

Pierse, N., Arnold, R., Keall, M., Howden-Chapman, P., Crane, J. and Cunningham, M. (2013). Modelling the effects of low indoor temperatures on the lung function of children with asthma. Journal of Epidemiology and Community Health, 67(11), 918-925.

Preval, N. (2012). An extended analysis of the impacts of retrofitted insulation and new heaters on health services utilisation and costs, and mortality: Evaluation of Warm Up New Zealand: Heat Smart Extension. Unpublished report prepared for Ministry of Economic Development. 
Preval, N. (2015). Statistical and policy evaluation of large-scale public health interventions ( $\mathrm{PhD}$ dissertation, University of Otago, Dunedin, New Zealand).

Preval, N., Keall, M., Telfar-Barnard, L., Grimes, A. and Howden-Chapman, P. (2017). Impact of improved insulation and heating on mortality risk of older cohort members with prior cardiovascular or respiratory hospitalisations. BMJ Open, 7(11), e018079.

Senate Committee (Environment, Communications and the Arts References Committee). (2010). Energy Efficient Homes Package (ceiling insulation) report. Canberra: Australian Government.

Telfar Barnard, L., Preval, N., Howden-Chapman, P., Arnold, R., Young, C., Grimes, A. and Denne, T. (2011). The impact of retrofitted insulation and new heaters on health services utilisation and costs, pharmaceutical costs and mortality: Evaluation of Warm Up New Zealand: Heat Smart (Report prepared for Ministry of Economic Development). Wellington: Motu Economic and Public Policy Research.

Wills, J. (2016). Locating localism: Statecraft, citizenship and democracy. Bristol, UK: Policy Press.

World Health Organization. (2011). Health in the green economy: Health co-benefits of climate change mitigation-housing sector. Geneva: World Health Organization. 
This text is taken from Agenda, Volume 26-Number 1, 2019, edited by William Coleman, published 2019 by ANU Press, The Australian National University, Canberra, Australia.

doi.org/10.22459/AG.26.01.2019.03 